\title{
Impact of Nitrogen Fertilization Levels on Morphophysiological Characters and Yield Quality of Some Maize Hybrids (Zea mays L.)
}

\author{
E. M. Hafez ${ }^{\#}$ and Kh. A.A. Abdelaal\# \\ Agronomy Dept. and *Agricultural Botany Dept., Faculty of \\ Agriculture, Kafrelsheikh University, Kafrelsheikh, Egypt.
}

\begin{abstract}
AIELD experiment was conducted in two successive seasons 2012 and 2013 at the experimental farm, faculty of agriculture, Kafrelsheikh University, Egypt, to investigate the effect of different nitrogen levels on growth, yield and quality of grains and forage of some maize hybrids (Zea mays L.). A split plot design with four replicates was used. Main plots consisted of four nitrogen levels (60, 90,120 and $150 \mathrm{~kg}$ urea/fed) and subplots, including three hybrids of maize (S.C.10, S.C.122 and S.C.124). Results indicated that the effect of nitrogen fertilizer and hybrids effects on chlorophyll $a$ and $b$, leaf area, the number of grains per ear, number of grains per row, 100 grain weight of maize, grain yield were significant. The S.C.10 was significantly higher than other hybrids in all traits under study except shelling percentage and crude fiber $\%$, which could increase palatability and digestibility of the hybrid. There was no significant difference occur among hybrids in crude fat in both seasons. $\mathrm{N}$ management by the application of $150 \mathrm{~kg} \mathrm{~N} / \mathrm{fed}$ produced significantly more leaf area, number of grains row ${ }^{-1}$, number of grains ear $^{-1}, 100$-grain weight $(\mathrm{g})$, grain yield (ard /fed), crude fat $(\%)$, fresh forage yield (ton/fed, protein $(\%)$ in forage yield and grain protein $(\%)$ however it had the lowest crude fiber $\%$. Furthermore, there was not find significant difference among $\mathrm{N}$ fertilizer levels on oil (\%) and moisture (\%), however, application of $120 \mathrm{~kg} \mathrm{~N} / \mathrm{fed}$. produced significantly more shelling (\%) and fresh forage yield (ton/fed). Thus, it concluded that applying $150 \mathrm{~kg} \mathrm{~N} /$ fed for S.C.10. could be used successfully for improving production of maize grain and forage yield as well as quality traits.
\end{abstract}

Keywords: Zea mays L., N fertilizer, Physiological characters, Grain yield, Quality.

Maize (Zea mays L.) an important cereal crop of the world, ranked $1^{\text {st }}$ in seed yield production (Stephen et al., 2006). Maize is one of the important cereal crops in the world's agricultural economy both as food for men and feed for animals (Chandrasekaran et al., 2010). In Egypt it is the third most important staple food crop both in terms of area and production after wheat and rice. Total area under cultivation of maize in Egypt is 888329 hectares which is about $25.17 \%$ of the total cultivated agricultural land while average yield is 7.80 ton $\mathrm{ha}^{-1}$.

\footnotetext{
${ }^{\#}$ Corresponding authors emails: emadhafez2014@gmail.com and khaled_elhaies@yahoo.com.
} 
It is about $21.90 \%$ of the total cereals production (FAO, 2011). Nitrogen is vital for most plant metabolic activities and plays an important role in tillering, stalk elongation and photosynthesis (Koochekzadeh et al., 2009). Its deficiency results in leaf area reduction which causes decreased photosynthesis which in turn leads to suppression of yields and crop quality (Sreewarome et al., 2007). The crop has a wider range of uses. These include the following: human food, industrial processed food production of starch and used as forage to feed animals.

Nitrogen fertilization is known to affect the grain production and $\mathrm{N}$ concentration of maize (Zea mays L.). Increasing $\mathrm{N}$ fertilization applications resulted in higher grain $\mathrm{N}$ concentrations (Abou El-Hassan et al., 2014). Maize plant as a whole is an important forage for many dairy and beef animals. The crop is palatable, quick growing with a high dry matter production and relatively high nutritive value. Dry matter yield of maize is a function of numerous interacting environmental and genetic factors. Temperature and available soil water are major environmental factors, with subsequent influence on leaf area development and subsequent dry matter yield (Dwyer \& Stewart, 1986). Maize is commonly fed to livestock as fodder forage or silage (Christopher et al., 1966). The feeding of corn fodder is popular in the semi-arid as well as in areas where corn often fails to reach the stage of mature grain. The stalks of the crop at this stage are more palatable and higher in protein than other stages (John \&Warren, 1967).

Nitrogen fertilization increased dry matter production, chlorophyll content and leaf area. The increase in leaf to stem ratio with nitrogen application is probably due to the increase in number of leaves and leaf area, producing more and heavy leaves (Gasim, 2001). John \& Warren (1967) and Muhammad et al. (2012) noted that the addition of nitrogen increased number of grains per row and ear. Koul (1997) recorded that nitrogen application resulted in greater values of grain yield and fresh forage yield were also increased due to addition of nitrogen. Significant differences among maize genotypes in yield and its components were frequently detected by many investigators (Zeynali et al., 2005; Zandi, 2012 and Hejazi \& Soleymani, 2014). N application at $80 \mathrm{~kg} \mathrm{~N} \mathrm{ha}^{-1}$ and $500 \mathrm{~kg} \mathrm{ha}^{-1}$ rates of lime significantly increased the crop productivity compared to those sown at other $\mathrm{N}$ and lime rates (Effa et al., 2012).

Maize grain yield per unit area involves multiplying the number of rows per ear, number of kernels per row and grain yield is affected by genotype and environment modified and may reduce or increase. Nitrogen availability affects plant growth and may cause changes in yield components. Increase the rate of accumulation of dry weight of aerial plant population and grain yield per unit area increases, because the increase in leaf area increase the growth rate of the product (Hejazi \& Soleymani, 2014). Hence, to improve yield and quality of maize fodder, it is indispensable to decide its nitrogen requirement as the application of nitrogen not only affects the forage yield of maize but also improve its quality especially its protein contents (Khandakar \& Islam, 1988). Although the present varieties/hybrids of maize have good yield potential but still yield per feddan is much less to tackle the food security threat.

Egypt. J. Agron. 37, No. 1 (2015) 
IMPACT OF NITROGEN FERTILIZATION LEVELS ...

So, this is the need of time to develop an $\mathrm{N}$ management strategy using the available high yielding varieties. So, our study was planned to evaluate the effect of $\mathrm{N}$ applications on the yield, forage yield, yield components, and quality attributes of maize hybrids.

\section{Plant materials}

\section{Materials and Methods}

Three maize hybrids, i.e. hybrid single cross (S.C.) 10, 122 and 124 (Table 1), all of which are widely cultivated in Egypt and four $\mathrm{N}$ fertilization levels, i.e. 60, $90,120,150 \mathrm{~kg} \mathrm{~N} / \mathrm{fed}$ were used to study the effect of nitrogen fertilizer levels in two successive seasons 2012 and 2013 on some morphophysiological characters, yield and its components, quality characters and forage yield for three single crosses of maize. The grains were sown on 10 June in 2012 and 14 June in 2013 at the experimental farm, faculty of agriculture, Kafrelsheikh University. A splitplot design with four replications conducted in both seasons, main plots were assigned to nitrogen fertilization levels, while, maize hybrids were randomly distributed in the sub-plots. The size of the sub-plot was $25.2 \mathrm{~m}^{2}$ (6 rows each row $6 \mathrm{~m}$ long and $70 \mathrm{~cm}$ rows spacing). Grains were planted in hills spaced $25 \mathrm{~cm}$ apart within the row. Maize plants were later thinned to one plant per hill. The first irrigation was applied after 21 days from sowing, while the following irrigations were applied at two or three weeks intervals. Handing hoeings were done before the first and second irrigations and pesticides were sprayed as necessary. Nitrogen fertilizer, according to the treatment, was applied in the form of urea $(46.5 \% \mathrm{~N})$ in two equal doses before the first and second irrigation. Other cultural practices for growing maize were conducted as recommended.

TABLE 1. The pedigree of maize hybrids.

\begin{tabular}{|l|c|}
\hline Hybrids & Pedigree \\
\hline SC10 & Sids-7 x Sd-63 \\
\hline SC122 & Giza-628 x Gz-603 \\
\hline SC124 & Giza-629 x Gz-603 \\
\hline
\end{tabular}

Soil samples were taken for conducting some mechanical and chemical analyses according to A.O. A.C. (2005) and all the data were shown in Tables 2 and 3.

TABLE 2. Mechanical properties of soil used in growing seasons 2012 and 2013.

\begin{tabular}{|c|c|c|c|c|}
\hline Year & Clay (\%) & Silt (\%) & Sand $(\boldsymbol{\%})$ & Textural class \\
\hline 2012 & 46.0 & 36.9 & 17.1 & clay \\
\hline 2013 & 49.0 & 35.2 & 15.1 & clay \\
\hline
\end{tabular}


TABLE 3. Chemical properties of soil used in growing seasons 2012 and 2013.

\begin{tabular}{|c|c|c|c|c|c|c|}
\hline Year & $\mathbf{N}(\mathbf{p p m})$ & $\mathbf{P}(\mathbf{p p m})$ & $\begin{array}{c}\mathbf{K} \\
(\mathbf{p p m})\end{array}$ & $\begin{array}{c}\text { Organic matter } \\
(\mathbf{\%})\end{array}$ & $\mathbf{P H}$ & $\mathbf{E C}\left(\mathbf{d s m}^{\mathbf{- 1}}\right)$ \\
\hline 2012 & 33.5 & 12.70 & 291.55 & 1.5 & 8.2 & 0.335 \\
\hline 2013 & 26.3 & 11.45 & 292.32 & 1.6 & 8.1 & 0.337 \\
\hline
\end{tabular}

Sakha meteorological station data, during 2012 and 2013 seasons, were recorded. Meteorological data having air temperature, relative humidity (\%), and pan evaporation from class A pan are presented in Tables 4 and 5.

TABLE 4. Soil moisture constants for the experimental site.

\begin{tabular}{|l|c|c|c|c|c|}
\hline $\begin{array}{c}\text { Soil depth } \\
(\mathbf{c m})\end{array}$ & $\begin{array}{c}\text { Field capacity } \\
(\mathbf{\%})\end{array}$ & $\begin{array}{c}\text { Wilting point } \\
(\mathbf{\%})\end{array}$ & \multicolumn{2}{|c|}{$\begin{array}{c}\text { Bulk density } \\
\left(\mathbf{g} / \mathbf{c m}^{\mathbf{3}}\right)\end{array}$} & \multicolumn{2}{|c|}{$\begin{array}{c}\text { Available soil } \\
\text { water }\end{array}$} \\
\cline { 5 - 6 } & & & & $\mathbf{\%}$ & $\mathbf{m m} / \mathbf{d a y}$ \\
\hline $0-15$ & 44.12 & 27.31 & 1.34 & 21.51 & 33.13 \\
$15-30$ & 42.23 & 25.30 & 1.56 & 17.03 & 29.76 \\
$30-45$ & 38.42 & 21.56 & 1.65 & 15.28 & 26.59 \\
$45-60$ & 35.36 & 20.29 & 1.72 & 14.37 & 23.32 \\
\hline
\end{tabular}

TABLE 5. Monthly accumulative pan evaporation (A.P.E), air temperature ${ }^{\circ} \mathrm{C}$ and relative humidity (\%) during 2012 and 2013 seasons.

\begin{tabular}{|c|c|c|c|c|c|c|c|c|c|c|c|c|c|c|}
\hline \multirow{3}{*}{\begin{tabular}{|l} 
Seasons \\
\\
Months
\end{tabular}} & \multicolumn{6}{|c|}{2012} & \multirow{3}{*}{$\begin{array}{c}\text { Pan } \\
\text { evaporation } \\
(\mathrm{mm} / \mathrm{day})\end{array}$} & \multicolumn{6}{|c|}{2013} & \multirow{3}{*}{$\begin{array}{c}\text { Pan } \\
\text { evaporation } \\
(\mathbf{m m} / \text { day })\end{array}$} \\
\hline & \multicolumn{3}{|c|}{$\begin{array}{c}\text { Air temperature } \\
{ }^{\circ} \mathbf{C} \\
\end{array}$} & \multicolumn{3}{|c|}{\begin{tabular}{|c|} 
Relative humidity \\
$(\%)$ \\
\end{tabular}} & & \multicolumn{3}{|c|}{\begin{tabular}{|c|}
$\begin{array}{c}\text { Air temperature } \\
{ }^{\circ} \mathbf{C}\end{array}$ \\
\end{tabular}} & \multicolumn{3}{|c|}{$\begin{array}{c}\text { Relative humidity } \\
(\%) \\
\end{array}$} & \\
\hline & Max. & Min. & Mean & Max. & Min. & Mean & & Max. & Min. & Mean & Max. & Min. & Mean & \\
\hline June & 30.8 & 16.2 & 23.8 & 80.1 & 45.0 & 62.6 & 7.24 & 33.2 & 16.5 & 24.9 & 69.0 & 46.0 & 57.5 & 8.40 \\
\hline July & 32.0 & 18.0 & 25.0 & 80.4 & 43.0 & 61.7 & 8.13 & 29.5 & 15.9 & 22.7 & 79.0 & 46.0 & 62.5 & 8.08 \\
\hline August & 31.7 & 18.4 & 25.1 & 86.0 & 53.0 & 69.5 & 8.00 & 32.7 & 19.1 & 25.9 & 86.3 & 50.0 & 68.2 & 8.41 \\
\hline September & 34.0 & 20.0 & 27.0 & 92.3 & 52.1 & 72.2 & 7.10 & 34.3 & 19.8 & 27.1 & 96.0 & 62.0 & 79.0 & 6.86 \\
\hline
\end{tabular}

\section{Sampling and measurements}

In 2012 and 2013, five guarded plants from each sub-plot were randomly taken from the second inner ridge at 60 days after sowing (DAS) to measure dry matter production, $\mathrm{Chl} \mathrm{a}, \mathrm{Chl} \mathrm{b}$ and leaf area. To measure dry weight of leaves and stems, samples were oven-dried at $70^{\circ} \mathrm{C}$ until a constant weight. Each part of the plant sample was ground into powder for the determination of total nitrogen content by the Kjeldahl method. The leaf chlorophyll content was determined in representative samples, which was taken from ear-leaf by spectrocolorimeter, using N, N-Dimethyl formamide, according to Moran \& Porath (1982). Chlorophyll contents were calculated according to the following formula:

Chl. $\mathrm{a}=12.64 \mathrm{~A}_{664}-2.99 \mathrm{~A}_{647}$.

Chl.b $=-5.6 \mathrm{~A}_{664}+23.26 \mathrm{~A}_{647}$.

Egypt. J. Agron. 37, No. 1 (2015) 
IMPACT OF NITROGEN FERTILIZATION LEVELS ...

Leaf area/plant in $\mathrm{dm}^{2}$ measured according to Alessi \& Power (1975) using the following formula: Leaf area (LA) = leaf length $\mathrm{x}$ maximum leaf width $\mathrm{x}$ 0.75. Leaf area in $\mathrm{dm}^{2}$ of three plants were summed and the leaf area/plant was calculated.

At harvest the following characters were recorded from the inner ridges in each sub-plot: number of grains row $^{-1}$, number of grains ear ${ }^{-1}, 100$-kernel weight, shelling $\%=$ (weight of grains of five ears/ weight of five ears) and the ears of two inner ridges were harvested in each sub-plot and shelled, and the grains were weighted and adjusted to $15.5 \%$ moisture and then transformed to ard/fed . Also to determine grain quality random sample of 200 grams of grains taken of ten ears, randomly. These grains were ground for characters as follows: Grain protein $(\%)$ of grains was estimated by the modified Kjeldahl method (A.O.A.C, 1964). Oil \% of grains was estimated by Sockselt method (A.O.C.S, 1980) and grain moisture \% was estimated using Moisture Tester Model 400M (Dole). Also was determined fiber quality as follows: The protein $(\%)$ of forage yield, the crude leaf fiber $\%$, crude fat $\%$ and fresh forage yield (ton $\mathrm{fed}^{-1}$ ).

Statistical analysis

All data were statistically analyzed according to procedures outlines by Gomez \& Gomez (1984). The mean values of studied factors were compared at 0.01 and 0.05 level of significance by the Duncan's multiple range test (Duncan, 1955).

\section{Results and discussions}

Effect of maize hybrids and $N$ fertilizer levels ( $\mathrm{kg} N / f e d)$

Results in Table 6 showed that $\mathrm{N}$ fertilizer levels significantly influenced dry matter production, $\mathrm{Chl}$ a and $\mathrm{Chl} \mathrm{b}$ at anthesis date on maize hybrids in both successive seasons under study. Dry matter production, Chl a, Chl b and leaf area at anthesis date were the highest at S.C.10 as compared to S.C.122 and S.C.124 the difference in chlorophyll content among hybrids are mainly attributed to the difference in genetical factors. These results supported those obtained by Bahr et al. (2006), Szulc et al. (2008) and Hafez et al. (2014). Regarding the effect of nitrogen levels on dry matter production, Chl a, Chl b and leaf area, there were significantly increased with increasing nitrogen levels up to $150 \mathrm{~kg} \mathrm{~N} / \mathrm{fed}$ at anthesis date in both successive seasons. This may be due to the role of nitrogen in increasing leaf area and chlorophyll content of leaves. This in turn caused an increase in photosynthetic nitrogen levels. Similar results were obtained by Bahr et al. (2006) and Hafez et al. (2014). The increase in leaf area could possibly be ascribed to the fact that nitrogen increases plant growth and plant height and this resulted in more nodes and internodes and subsequently more production of le12345aves (Amin, 2011). In this respect, Jhones et al. (1995) found that nitrogen fertilization, significantly increased the number of leaves and they suggested that the increasing in number of leaves may be as a result of increasing number of nodes.

Egypt. J. Agron. 37, No. 1 (2015) 
TABLE 6. Dry matter production, Chl a, Chl b and leaf area at anthesis date as affected by some maize hybrids and different nitrogen levels $(\mathrm{kg} \mathrm{N} / \mathrm{fed})$ during 2012 and 2013 seasons.

\begin{tabular}{|c|c|c|c|c|c|c|c|c|}
\hline \multirow[t]{2}{*}{ Treatments } & \multicolumn{2}{|c|}{ DMP (g/plant) } & \multicolumn{2}{|c|}{ Chl.a (mg dm $\left.{ }^{-2}\right)$} & \multicolumn{2}{|c|}{ Chl.b (mg dm $\left.{ }^{-2}\right)$} & \multicolumn{2}{|c|}{$\begin{array}{c}\text { Leaf area } \\
\left(\mathrm{dm}^{2} / \text { plant }\right)\end{array}$} \\
\hline & 2012 & 2013 & 2012 & 2013 & 2012 & 2013 & 2012 & 2013 \\
\hline Maize hybrids $(\mathrm{H})$ & & & & & & & & \\
\hline S.C.10 & $174.87 \mathrm{a}$ & $148.54 \mathrm{a}$ & $7.56 \mathrm{a}$ & $6.78 \mathrm{a}$ & $2.67 \mathrm{a}$ & $1.92 \mathrm{a}$ & $77.99 \mathrm{a}$ & $81.25 \mathrm{a}$ \\
\hline S.C. 122 & $151.12 \mathrm{~b}$ & $122.44 b$ & $7.24 \mathrm{~b}$ & $5.52 \mathrm{~b}$ & $2.45 \mathrm{~b}$ & $1.63 \mathrm{~b}$ & $74.75 b$ & $76.45 \mathrm{~b}$ \\
\hline S.C. 124 & $138.55 \mathrm{c}$ & $113.98 \mathrm{c}$ & $7.24 \mathrm{~b}$ & $5.72 \mathrm{~b}$ & $2.29 \mathrm{c}$ & $1.65 \mathrm{~b}$ & $72.85 \mathrm{c}$ & $72.42 \mathrm{c}$ \\
\hline F-Test & $*$ & $*$ & $* *$ & $*$ & $* *$ & $*$ & $*$ & $*$ \\
\hline $\begin{array}{l}\text { N-fertilization level } \\
\text { (kg N/fed) }\end{array}$ & & & & & & & & \\
\hline 60 & $154.87 \mathrm{c}$ & $112.78 \mathrm{c}$ & $6.05 \mathrm{~d}$ & $4.75 \mathrm{~d}$ & $2.37 \mathrm{~d}$ & $1.45 \mathrm{c}$ & $71.55 \mathrm{~d}$ & $74.89 \mathrm{~d}$ \\
\hline 90 & $163.23 b$ & $128.65 b$ & $6.53 \mathrm{c}$ & $5.06 \mathrm{c}$ & $2.67 \mathrm{c}$ & $1.65 \mathrm{~b}$ & $76.25 \mathrm{c}$ & $78.25 c$ \\
\hline 120 & $178.55 \mathrm{a}$ & $134.69 a$ & $6.96 \mathrm{~b}$ & $5.29 \mathrm{~b}$ & $2.80 \mathrm{~b}$ & $1.82 \mathrm{a}$ & $79.35 b$ & $81.67 \mathrm{~b}$ \\
\hline 150 & $181.68 \mathrm{a}$ & $139.54 \mathrm{a}$ & $7.45 \mathrm{a}$ & $5.48 \mathrm{a}$ & $2.96 \mathrm{a}$ & $1.85 \mathrm{a}$ & $83.12 \mathrm{a}$ & $85.25 \mathrm{a}$ \\
\hline F-Test & $*$ & $*$ & $* *$ & $*$ & $*$ & $*$ & $*$ & $*$ \\
\hline $\mathrm{H} \times \mathrm{N}$ interaction & ns & ns & ns & ns & ns & ns & $\mathrm{ns}$ & $\mathrm{ns}$ \\
\hline
\end{tabular}

**: highly significant at the $1 \%$ level of probability . Means within the same column of each factor followed by a common latter is not significantly different at $5 \%$ level, by DMRT.

Data in Table 7 showed that S.C.10 surpassed significantly than S.C.122 and S.C.124 in number of grains row $^{-1}$, number of grains ear $^{-1}, 100$-grain weight $(\mathrm{g})$ and grain yield (ard/fed) during the two successive seasons. The differences in hybrids may be due to the differences in their genetic make up to stress condition and environmental factors affecting developmental processes and ability to thrive and benefit after the available nutrients. Similar results were obtained by Bahr et al. (2006) and Hejazi \& Soleymani (2014). In addition to high efficiency of that hybrid in photosynthesis process which led to an increase in dry matter production this is in harmony with that obtained by Bahr et al. (2006). The data in Table 2 indicated that increasing nitrogen level up to $150 \mathrm{~kg} \mathrm{~N} / \mathrm{fed}$ led to significant increasing in number of grains row $^{-1}$, number of grains ear ${ }^{-1}, 100$-grain weight $(\mathrm{g})$ and grain yield ( $\mathrm{ard} / \mathrm{fed})$ in both successive seasons. The positive increase in yield components demonstrates that $\mathrm{N}$ increased assimilates supply for component development and yield set (Akmal et al., 2010). These results might be attributed to the effect of nitrogen on the vigor vegetative growth and accumulation of photosynthesis assimilates which produce high number of grains/row and grains/ear and meristematic activity of maize plant and increasing yield attributes as final grain yield. These results are in accordance with Bahr et al. (2006) and Shapiro \& Wortmann (2006).

From Table 8, it could be noticed that shelling $\%$ had a significant effect for S.C.124 in both seasons than S.C.10 and S.C.122. Similar results were reported by El-Moursy \& Badwai (1998) and no significant difference among hybrids on crude fat $\%$ in both seasons. Both of fresh forage yield and protein $\%$ in forage had a high significant difference among hybrids whereas S.C.10 and S.C.122 showed the highest values than S.C.124 in both seasons. These single crosses could be useful for utilization in silage production and animals feeding. Similar results were reported by Radwan et al. (2001).

Egypt. J. Agron. 37, No. 1 (2015) 
IMPACT OF NITROGEN FERTILIZATION LEVELS ...

TABLE 7. No. of grains row ${ }^{-1}$, number of grains ear $^{-1}, 100$-grain weight (g) and grain yield (ard /fed) as affected by some maize hybrids and different nitrogen levels (kg N/fed) during 2012 and 2013 seasons.

\begin{tabular}{|l|c|c|c|c|c|c|c|c|}
\hline \multirow{2}{*}{ Treatments } & \multicolumn{2}{|c|}{$\begin{array}{c}\text { No. of grains } \\
\text { row-1 }\end{array}$} & \multicolumn{2}{c|}{$\begin{array}{c}\text { No.of grains } \\
\text { ear-1 }\end{array}$} & \multicolumn{2}{c|}{$\begin{array}{c}\text { 100-grain } \\
\text { weight (g) }\end{array}$} & \multicolumn{2}{c|}{$\begin{array}{c}\text { Grain yield } \\
\text { (ard/fed) }\end{array}$} \\
\cline { 2 - 9 } & $\mathbf{2 0 1 2}$ & $\mathbf{2 0 1 3}$ & $\mathbf{2 0 1 2}$ & $\mathbf{2 0 1 3}$ & $\mathbf{2 0 1 2}$ & $\mathbf{2 0 1 3}$ & $\mathbf{2 0 1 2}$ & $\mathbf{2 0 1 3}$ \\
\hline Cultivars(V) & & & & & & & & \\
S.C.10 & $46.3 \mathrm{a}$ & $47.8 \mathrm{a}$ & $378.5 \mathrm{a}$ & $387.4 \mathrm{a}$ & $47.66 \mathrm{a}$ & $43.56 \mathrm{a}$ & $29.25 \mathrm{a}$ & $26.45 \mathrm{a}$ \\
S.C.122 & $44.5 \mathrm{~b}$ & $45.5 \mathrm{~b}$ & $360.3 \mathrm{~b}$ & $374.2 \mathrm{~b}$ & $42.45 \mathrm{~b}$ & $35.54 \mathrm{~b}$ & $24.55 \mathrm{c}$ & $19.67 \mathrm{c}$ \\
S.C.124 & $43.4 \mathrm{~b}$ & $44.3 \mathrm{~b}$ & $355.4 \mathrm{~b}$ & $359.8 \mathrm{c}$ & $43.78 \mathrm{~b}$ & $36.43 \mathrm{~b}$ & $27.45 \mathrm{~b}$ & $22.58 \mathrm{~b}$ \\
\hline F-Test & $* *$ & $* *$ & $* *$ & $* *$ & $* *$ & $* *$ & $* *$ & $* *$ \\
\hline N-fertilization & & & & & & & & \\
level (kg N/fed) & & & & & & & & \\
& & & & & & & & \\
60 & $42.5 \mathrm{~d}$ & $43.3 \mathrm{~d}$ & $285.9 \mathrm{~d}$ & $291.5 \mathrm{~d}$ & $43.22 \mathrm{c}$ & $39.65 \mathrm{c}$ & $23.85 \mathrm{~d}$ & $20.40 \mathrm{~d}$ \\
90 & $45.8 \mathrm{c}$ & $46.3 \mathrm{c}$ & $312.5 \mathrm{c}$ & $322.4 \mathrm{c}$ & $44.38 \mathrm{~b}$ & $39.55 \mathrm{c}$ & $25.55 \mathrm{c}$ & $22.25 \mathrm{c}$ \\
120 & $46.5 \mathrm{~b}$ & $46.9 \mathrm{~b}$ & $345.8 \mathrm{~b}$ & $353.4 \mathrm{~b}$ & $44.88 \mathrm{~b}$ & $40.55 \mathrm{~b}$ & $27.78 \mathrm{~b}$ & $25.85 \mathrm{~b}$ \\
150 & $47.7 \mathrm{a}$ & $48.1 \mathrm{a}$ & $408.3 \mathrm{a}$ & $422.3 \mathrm{a}$ & $45.75 \mathrm{a}$ & $41.25 \mathrm{a}$ & $28.38 \mathrm{a}$ & $26.32 \mathrm{a}$ \\
\hline F-Test & $* *$ & $* *$ & $* *$ & $* *$ & $* *$ & $* *$ & $* *$ & $* *$ \\
\hline V $\times$ N interaction & $\mathrm{ns}$ & $\mathrm{ns}$ & $\mathrm{ns}$ & $\mathrm{ns}$ & $\mathrm{ns}$ & $\mathrm{ns}$ & $* *$ & $* *$ \\
& & & & & & & & \\
\hline
\end{tabular}

: highly significant at the $1 \%$ level of probability. Means within the same column of each factor followed by a common latter is not significantly different at $5 \%$ level, by DMRT .

TABLE 8. Shelling (\%), crude fat (\%), fresh forage yield (ton/fed) and protein (\%) in forage yield as affected by some Maize hybrids and different nitrogen levels (kg N/fed) during 2012 and 2013 seasons.

\begin{tabular}{|l|c|c|c|c|c|c|c|c|}
\hline \multirow{2}{*}{ Treatments } & \multicolumn{2}{|c|}{ Shelling (\%) } & \multicolumn{2}{c|}{$\begin{array}{c}\text { Crude fat } \\
(\%)\end{array}$} & \multicolumn{2}{c|}{$\begin{array}{c}\text { Fresh forage yield } \\
\text { (ton/fed) }\end{array}$} & \multicolumn{2}{c|}{$\begin{array}{c}\text { Protein (\%) in } \\
\text { forage }\end{array}$} \\
\cline { 2 - 9 } & $\mathbf{2 0 1 2}$ & $\mathbf{2 0 1 3}$ & $\mathbf{2 0 1 2}$ & $\mathbf{2 0 1 3}$ & $\mathbf{2 0 1 2}$ & $\mathbf{2 0 1 3}$ & $\mathbf{2 0 1 2}$ & $\mathbf{2 0 1 3}$ \\
\hline Cultivars(V) & & & & & & & \\
S.C.10 & $80.32 \mathrm{c}$ & $78.43 \mathrm{c}$ & 3.01 & 3.34 & $15.34 \mathrm{a}$ & $14.56 \mathrm{a}$ & $2.75 \mathrm{a}$ & $2.85 \mathrm{a}$ \\
S.C.122 & $82.28 \mathrm{~b}$ & $81.88 \mathrm{~b}$ & 2.88 & 3.25 & $15.11 \mathrm{a}$ & $13.98 \mathrm{a}$ & $2.64 \mathrm{a}$ & $2.76 \mathrm{a}$ \\
S.C.124 & $84.47 \mathrm{a}$ & $83.12 \mathrm{a}$ & 2.75 & 3.12 & $12.24 \mathrm{~b}$ & $11.55 \mathrm{~b}$ & $2.38 \mathrm{~b}$ & $2.48 \mathrm{~b}$ \\
\hline F-Test & $* *$ & $* *$ & $\mathrm{~ns}$ & $\mathrm{~ns}$ & $* *$ & $* *$ & $* *$ & $* *$ \\
\hline N-fertilization level & & & & & & & & \\
(kg N/fed) & & & & & & & & \\
60 & $80.56 \mathrm{~d}$ & $82.55 \mathrm{~d}$ & $2.35 \mathrm{~d}$ & $2.55 \mathrm{~d}$ & $10.92 \mathrm{~d}$ & $11.65 \mathrm{c}$ & $2.05 \mathrm{~d}$ & $2.25 \mathrm{~d}$ \\
90 & $82.78 \mathrm{~b}$ & $82.89 \mathrm{~b}$ & $2.85 \mathrm{c}$ & $3.12 \mathrm{c}$ & $12.54 \mathrm{c}$ & $13.75 \mathrm{~b}$ & $2.38 \mathrm{c}$ & $2.45 \mathrm{c}$ \\
120 & $83.54 \mathrm{a}$ & $83.22 \mathrm{a}$ & $3.15 \mathrm{~b}$ & $3.29 \mathrm{~b}$ & $14.67 \mathrm{~b}$ & $14.45 \mathrm{a}$ & $2.62 \mathrm{~b}$ & $2.75 \mathrm{~b}$ \\
150 & $81.98 \mathrm{c}$ & $82.25 \mathrm{c}$ & $3.55 \mathrm{a}$ & $3.72 \mathrm{a}$ & $16.25 \mathrm{a}$ & $15.78 \mathrm{a}$ & $2.88 \mathrm{a}$ & $3.15 \mathrm{a}$ \\
\hline F-Test & $* *$ & $* *$ & $* *$ & $* *$ & $* *$ & $* *$ & $* *$ & $* *$ \\
\hline V $\times$ N interaction & $\mathrm{ns}$ & $\mathrm{ns}$ & $\mathrm{ns}$ & $\mathrm{ns}$ & $* *$ & $* *$ & $\mathrm{~ns}$ & $\mathrm{~ns}$ \\
\hline
\end{tabular}

${ }^{*}$ : highly significant at the $1 \%$ level of probability. Means within the same column of each factor followed by a common latter is not significantly different at $5 \%$ level, by DMRT . 
From the same table, it could be noticed that increasing nitrogen fertilizer level up to $150 \mathrm{~kg} \mathrm{~N} /$ fed led to significantly increase in crude fat $\%$, fresh forage yield and protein $\%$ in forage in both seasons. However increasing nitrogen fertilizer level up to $120 \mathrm{~kg} \mathrm{~N} /$ fed led to significantly increase than $150 \mathrm{~kg} \mathrm{~N} / \mathrm{fed}$ in shelling \% in both seasons. Similar results were reported by El-Moursy \& Badwi (1998). The increase in fresh yield of forage under nitrogen application can be attributed to the positive effect of nitrogen on all the investigated growth parameters in this study.

Data presented in Table 9 indicated that the variations between single crosses were highly significant for both of oil $\%$, crude fiber $\%$ and moisture $\%$ in both successive seasons, as well as protein $\%$ in the first season only. The highest values were obtained from S.C.10 in both seasons and the lowest for crude fiber \% which could increase palatability and digestibility of the hybrid. These results are mainly due to differences in the genetic make up of the evaluated hybrids and this in agreement with those reported by Almodares et al. (2009). Concerning the effect of nitrogen fertilizer levels, data in Table 4 revealed that nitrogen fertilizer levels significantly affected protein $\%$ and crude fiber $\%$. Protein $\%$ gradually increased by increasing $\mathrm{N}$ level from 60 up to $150 \mathrm{~kg} \mathrm{~N} / \mathrm{fed}$ in both seasons. However, increasing nitrogen fertilizer led to significantly decreasing in crude fiber \% in both seasons. Similar results were reported by Khan (2008), Almodares et al. (2009) and Iqbal et al. (2010). Regarding to oil \% and moisture \%, the results indicated that increasing of nitrogen fertilizer levels up to $150 \mathrm{~kg} \mathrm{~N} /$ fed did not show any significant increase in both seasons, this confirmed with Khan (2008) and Iqbal et al. (2010). Increasing grain protein content of maize may be due to an increase in available $\mathrm{N}$-around root zone, which increase nitrogen supply to plant under high fertilization level of nitrogen, whereas, nitrogen plays an important role in the synthesis of protein. Similar results were obtained by Koul (1997) and Almodares et al. (2009).

TABLE 9. Grain protein (\%), grain oil (\%), leaf crude fiber $(\%)$ and grain moisture $(\%)$ as affected by some maize hybrids and different nitrogen levels (kg N/fed) during 2012 and 2013 seasons.

\begin{tabular}{|c|c|c|c|c|c|c|c|c|}
\hline \multirow[t]{2}{*}{ Treatments } & \multicolumn{2}{|c|}{ Protein (\%) } & \multicolumn{2}{|c|}{ Oil (\%) } & \multicolumn{2}{|c|}{$\begin{array}{c}\text { Crude fiber } \\
(\%)\end{array}$} & \multicolumn{2}{|c|}{ Moisture (\%) } \\
\hline & 2012 & 2013 & 2012 & 2013 & 2012 & 2013 & 2012 & 2013 \\
\hline Cultivars(V) & & & & & & & & \\
\hline S.C.10 & $10.95 \mathrm{a}$ & 8.75 & $5.45 \mathrm{a}$ & $4.88 \mathrm{a}$ & $25.45 \mathrm{c}$ & $27.02 \mathrm{c}$ & $30.34 \mathrm{a}$ & $27.56 \mathrm{a}$ \\
\hline S.C. 122 & $10.07 \mathrm{~b}$ & 8.38 & $4.85 \mathrm{~b}$ & $4.25 b$ & $28.87 \mathrm{~b}$ & $29.23 b$ & $27.55 \mathrm{~b}$ & $24.43 b$ \\
\hline S.C.124 & $10.15 b$ & 8.44 & $4.88 \mathrm{~b}$ & $4.28 b$ & $29.43 a$ & $31.67 \mathrm{a}$ & $27.75 b$ & $23.78 b$ \\
\hline F-Test & $* *$ & ns & $* *$ & $* *$ & $* *$ & $* *$ & *** & *** \\
\hline $\begin{array}{l}\text { N-fertilization level } \\
\text { (kg N/fed) }\end{array}$ & & & & & & & & \\
\hline 60 & $9.04 \mathrm{c}$ & $8.55 \mathrm{~d}$ & 4.35 & 4.54 & $32.45 \mathrm{a}$ & $33.78 \mathrm{a}$ & 28.56 & 26.14 \\
\hline 90 & $9.38 \mathrm{~b}$ & $8.75 c$ & 4.46 & 4.66 & $29.56 b$ & $29.77 b$ & 28.85 & 26.35 \\
\hline 120 & $10.12 \mathrm{ab}$ & $9.12 b$ & 4.59 & 4.75 & $26.78 \mathrm{c}$ & $27.96 \mathrm{c}$ & 29.15 & 26.65 \\
\hline 150 & $10.33 \mathrm{a}$ & $9.59 \mathrm{a}$ & 4.58 & 4.72 & $24.68 d$ & $25.88 \mathrm{~d}$ & 29.32 & 26.95 \\
\hline F-Test & $* *$ & $* *$ & ns & ns & $* *$ & $* *$ & ns & ns \\
\hline $\mathrm{V} \times \mathrm{N}$ interaction & ns & ns & ns & ns & ns & ns & ns & ns \\
\hline
\end{tabular}

**: highly significant at the $1 \%$ level of probability. Means within the same column of each factor followed by a common latter is not significantly different at $5 \%$ level, by DMRT.

Egypt. J. Agron. 37, No. 1 (2015) 
IMPACT OF NITROGEN FERTILIZATION LEVELS ...

\section{Effect of the interaction}

The interaction between maize hybrids and nitrogen fertilizer levels had only significant effect on fresh forage yield (ton/fed) and grain yield (ard/fed) in the two growing seasons as shown in Tables 6 and 7 and graphically illustrated in Fig. 1 and 2. The significant highest values of these characters resulted from S.C.10 with application of $150 \mathrm{~kg} \mathrm{~N} / \mathrm{fed}$. Similar results have been reported by Oscar \& Tollenaar (2006) who found that the highest fresh forage yield were obtained by increasing both of leaf area and dry matter production, this may due to apply high $\mathrm{N}$ fertilizer level on the rate of growth of meristemic cells and the appearance and development of leaves (Ahmad et al., 1993). These results are in agreement with those reported by Bahr et al. (2006) and Hejazi \& Soleymani (2014), and were similar, more or less, with those obtained by Onasanya et al. (2009), Khaliq et al. (2009), Sharifi \& Taghizadeh (2009), Akmal et al. (2010), Hammad et al. (2011), Dawadi \& Sah (2012), Khan et al. (2012), Sharifai et al. (2012), Moraditochaee et al. (2012) and Kandil (2013).
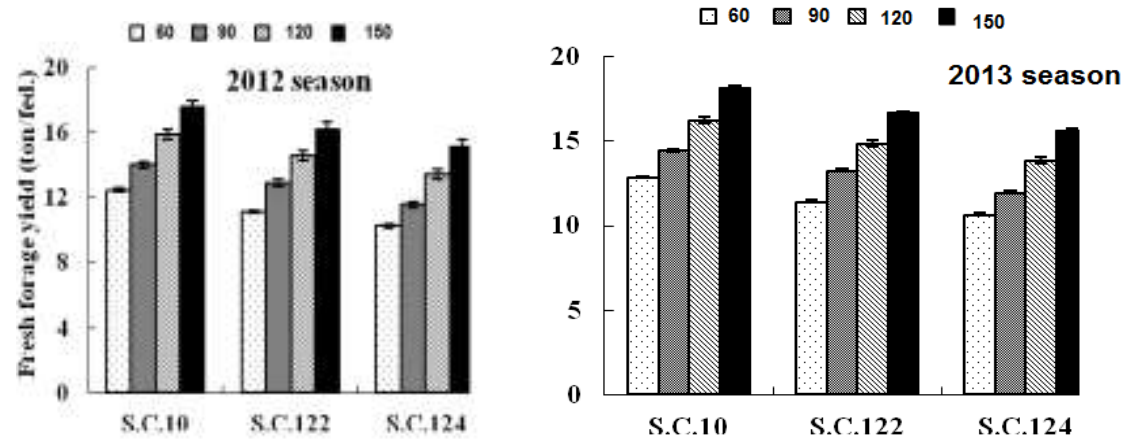

Fig. 1. Fresh forage yield (ton/fed) of maize as affected by the interaction between maize hybrids and nitrogen fertilizer levels (kg N/fed) during 2012 and 2013 seasons. The data are the mean \pm standard error of four replicates.

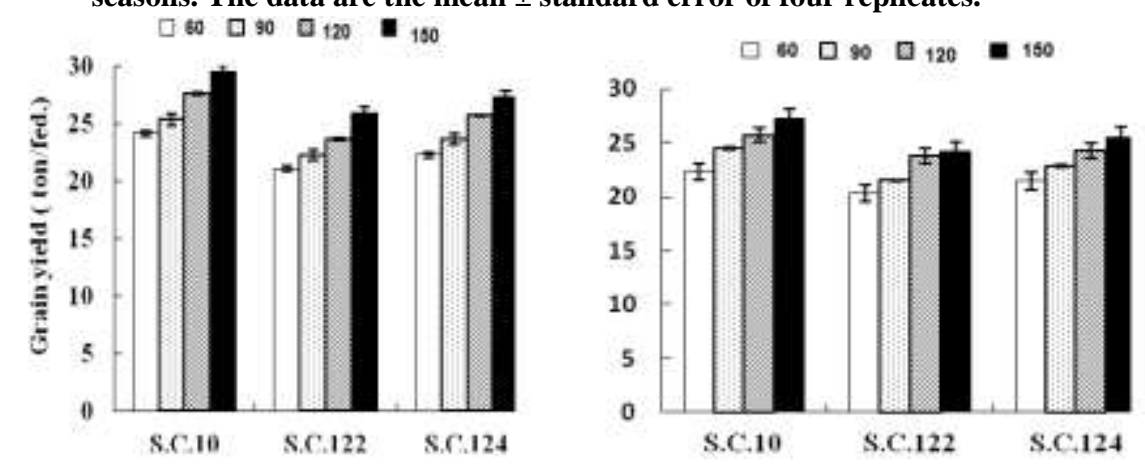

Fig. 2. Grain yield (ard/fed) of maize as affected by the interaction between maize hybrids and nitrogen fertilizer levels (kg N/fed) during 2012 and 2013 seasons. The data are the mean \pm standard error of four replicates. 


\section{Conclusion}

From the above results and discussion, protein and fiber content could be suitable parameters for determining forage quality. In contrary, fiber content has a negative effect on forage quality. Application of nitrogen fertilizer increased the amount of grain and forage protein content and decreased the fiber content in maize hybrids. Therefore, it seems that application of nitrogen fertilizer could increase palatability and digestibility of maize hybrids. Thus, based on above mentioned, it is suggested to apply $150 \mathrm{~kg} \mathrm{~N} / \mathrm{fed}$ among the nitrogen treatments and S.C.10 hybrid among the hybrids under the study, both of them together gave the highest values for all traits in this study.

\section{References}

Abou El-Hassan, W.H., Hafez, E. M., Ghareib, A.A.A., Freeg, M. R. and Seleiman , M. F. (2014) Impact of nitrogen fertilization and irrigation on water utilization efficiency, $\mathrm{N}$ accumulation, growth and yields of (Zea mays L.). Journal of Food, Agriculture \& Environment, 12(3\&4), 217-222.

Ahmad, R., Ahmad, N., Ahmad, S. and Ahmad, T. (1993) Source-sink relationships in maize under varying nitrogen regimes. Pak. J. Agric. Res. 14 (2), 173-76

Akmal, M., Rehman, H. U., Farhatullah, M. A. and Akbar, H. (2010) Response of maize varieties to nitrogen application for leaf area profile, crop growth, yield and yield components. Pakistan Journal of Botany, 42(3),1941-1947.

A.O.A.C (1964) "Offical Methods of Analysis" . Official Analytical Chemists, $13^{\text {th }}$ ed.Washington.

A.O.C.S (1980) "Official and Relative Methods of American Oil Chemicals Society". $2^{\text {nd }}$ ed. Published by American Oil Chemicals Society, 35, East Wacker Drive, Chicago, Illinois, U.S.A.

Alessi, J. and Power, I.E. (1975) Effect of plant spacing on phonological development of early and mid season corn hybrids in arid region. Crop Sci., 15,179-182.

Almodares, A., Jafarinia, M. and Hadi, M.R. (2009) The effects of nitrogen fertilizer on chemical compositions in corn and sweet sorghum. American-Eurasian J. Agric. Environ. Sci. 6(4), 441-446.

Amin, M. H. (2011) Effect of different nitrogen sources on gowth, yield and quality of fodder maize (Zea mays L.), J. Saudi Soc. Agric. Sci. 10, 17-23.

Bahr, Amany A., Zeidan, M. S. and Hozayn, M. (2006) Yield and quality of maize (Zea mays L.) as affected by slow- release nitrogen in newly reclaimed sandy soil. American-Eurasian J. Agric \& Environment. Sci. 1(3), 239-242.

Chandrasekaran, B., Annadura, K. and Somasundaram, E. (2010) Nutrient management "A Textbook of Agronomy", pp.548. Published by New Age International (P) Ltd., Publishers .

Egypt. J. Agron. 37, No. 1 (2015) 
IMPACT OF NITROGEN FERTILIZATION LEVELS ...

Christopher, R. D., Paliwal, R.L. and Ronald, P. (1966) The maize plant and its uses. In: "Maize in the Third World". pp. 17-34. United States of America.

Dawadi, D.R. and Sah, S.K. (2012) Growth and yield of hybrid maize (zea mays 1.) in relation to planting density and nitrogen levels during winter season in Nepal. Trop. Agri. Res. 23(3),218-227.

Duncan, B.D. (1955) Multiple ranges and multiple F-test. Biometri. 11, 1-42.

Dwyer, L.M. and Stewart, D.W. (1986) Leaf area development in field grow maize. Agron. J. 78, 334-343.

Effa, E. B., Uwah, D. F. Iwo, G. A. Obok, E. E. and Ukoha, G. O. (2012) Yield performance of popcorn (Zea mays L. everta) under lime and nitrogen fertilization on an acid soil, Journal of Agricultural Science, 4(10).

EL-Moursy, S.A. and Badawi, M.A. (1998) Nitrogen fertilizer levels and weedng regime effects on maize and its associated weeds. J. Agric. Sci.Mansoura Univ. 23(3), 997-1012.

F.A.O. (2011) "Food and Agriculture Organisation Statistics", FAOSTAT. www.fao.org/faostat.

Gasim, S.H. (2001) Effect of nitrogen, phosphorus and seed rate on growth, yield and quality of forage maize (Zea mays L.). M.Sc. Thesis, Faculty of Agric., Univ. of Khartoum.

Gomez, K.A. and Gomez, A.A. (1984) "Statistical Procedures for Agricultural Research". John Wiley and Sons, $2^{\text {nd }}$ ed. pp.180,New Yourk,U.S.A.

Hafez, E. M., Ragab, A.Y. and Kobata, T. (2014) Water-use efficiency and ammonium-N source applied of wheat under irrigated and desiccated conditions. International Journal of Plant \& Soil Science, 3(10), 1302-1316.

Hammad, H.M., Ahmad, A., Khaliq, T., Farhad, W. and Mubeen, M. (2011) Optimizing rate of nitrogen application for higher yield and quality in maize under semiarid environment. Crop \& Environ. 2(1), 38-41.

Hejazi, L. and Soleymani, A. (2014) Effect of different amounts of nitrogen fertilizer on grain yield of forage corn cultivars in Isfahan. International Journal of Advanced Biological and Biomedical Research, 2 (3), 608-614.

Iqbal, S., Khan, H.Z., Shaheen, H., Ali, A., Raza, S. and Kausar, R. (2010) Growth and yield response of spring maize (Zea mays L.) to different sources of nitrogen. Int. J. Agric. Appl. Sci. 2, 80-84.

John, H.M. and Warren, H.L. (1967) Pasture and pasturage. In: "Principle of Field Crop Production", pp. 257-258.

Jhones, R.M., Sanderson, M.A., Read, J.E. and Lovell , A.C. (1995) Management of corn for silage production in south central USA. J. Prod. Agric. 8 (2),175-180.

Egypt. J. Agron. 37, No. 1 (2015) 
Kandil, E.E.E. (2013) Response of some maize hybrids (Zea mays L.) to different levels of nitrogenous fertilization. Journal of Applied Sciences Research, 9(3), 1902-1908.

Khaliq, T., Ahmad, A., Hussain, A. and Ali, M.A. (2009) Maize hybrids response to nitrogen rates at multiple locations in semiarid environment. Pak. J. Bot. 41(1), 207-224.

Khan, H.Z. (2008) "Nitrogen Management Studies in Spring Maize". Dept. of Agron. Univ. Agric. Faisalabad, Pakistan.

Khan, N.W., Ijaz, N.K. and Khan, A. (2012) Integration of nitrogen fertilizer and herbicides for efficient weed management in maize crop. Sarhad J. Agric. 28(3).

Khandakar, Z.H. and Islam, M.M. (1988) Effect of nitrogen fertilization and stage of maturity on yield and quality of fodder maize Ban. J. Anim. Sci. 17(1-2), 47-53.

Koochekzadeh, A., Fathi, G., Gharineh, M. H., Siadat, S. A., Jafari, S. and AlamiSaeid, K. H. (2009) Impacts of rate and split application of $\mathrm{N}$ fertilizers on sugarcane quality. International Journal of Agricultural Research, 4, 116-123.

Koul, G.G. (1997) Effect of sowing methods, nitrogen levels and seed rates on yield and quality of fodder maize (Zea mays L.). M.Sc. Thesis, Univ. of Khartoum, Faculty of Agric.

Moraditochaee, M., Motamed, M.K., Azarpour, E., Danesh, R.K. and Bozorgi, H.R. (2012) Effects of nitrogen fertilizer and plant density Management in corn farming. ARPN Journal of Agricultural and Biological Science, 7(2), 133-137.

Moran, R. and Porath, D. (1982) Chlorophyll determination in intact tissues using N,NDimethyl formamide. Plant. Physiology, 69, 1370-1381.

Muhammad, A. Sh., Maqsood, M., Bhatti, M.A., Ahmad, W. and Shahid, M. R. (2012) Effects of nitrogen fertilization rate and harvest time on maize (Zea mays L.) fodder yield and its quality attributes. Asian. J. Pharm. Biol. Res. 2(1), 19-26.

Onasanya, R.O., Aiyelari, O.P., Onasanya, A., Oikeh, S., Nwilene, F.E. and Oyelakin, O.O. (2009) Growth and yield response of maize (Zea mays L.) to different rates of nitrogen and phosphorus fertilizers in southern Nigeria. World. $J$. Agric. Sci. 5(4), 400-407.

Oscar, R.V. and Tollenaar, M. (2006) Effect of genotype ,nitrogen, plant density and row spacing on the area-per-leaf profile in maize. Agron . J. 98, 94-99.

Radwan, M.S., El-Kalla, S.E., Sultan, M.S. and Abd El-Moneam, M.A. (2001) Differential response of maize hybrids to nitrogen fertilization. Proc. $2^{\text {nd }}$ Conf. Plant Breed., Assiut Univ., pp.121-138.

Shapiro, C.A. and Wortmann, C.S. (2006) Corn response to nitrogen rate, row spacing and plant density in Eastern Nebraska. Agron. J. 98, 529-535. 
IMPACT OF NITROGEN FERTILIZATION LEVELS ...

Sharifai, A.I., Mahmud, M., Tanimu, B. and Abubakar, I.U. (2012) Yield and yield components of extra early maize (Zea mays L.). as influenced by intra-row spacing, nitrogen and poultry manure rates. Bajopas. 5(1), 113-120.

Sharifi, R.S. and Taghizadeh, R. (2009) Response of maize (Zea mays L.) cultivars to different levels of nitrogen fertilizer. J. Food, Agri. \& Environ. 7(3\&4), 518-521.

Sreewarome, A., Saensupo, S., Prammanne, P. and Weerathworn, P. (2007) Effect of rate and split application of nitrogen on agronomic characteristics, cane yield and juice quality. Proceedings of International Society of Sugar Cane Technology, 26, 465-490.

Stephen, P.L., Zhu, X.G., Naid, S.L. and Donald, R. (2006) Can improvement in photosynthesis increase crop yield. Plant Cell and Environment, 29, 315-330

Szulc, P., Waligóra, H. and Skrzypczak, W. (2008) Effect of Fusarium culmorum on the content of chlorophyll depending on doses of nitrogen and the method of fertilization // Acta Agrophysica, (a), 11(2), 527-538.

Zandi, P. (2012) Effect of plant density on yield new hybrids of maize in the region. Master Thesis of Agronomy, Faculty of Agriculture, Islamic Azad University (Isfahan).

Zeynali, H., Abadi, N . and Zadeh, A. H. (2005) Factor analysis of the maize varieties. Iranian Journal of Agricultural Science, 36 (4), 895-902.

(Received 9/2/2015; accepted 5/3/2015) 


\section{تأثير معدلات التسميد النيتروجينى على الصفات المورفولوجية

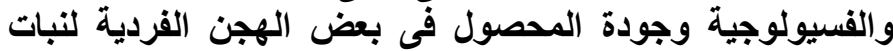

عماد الاين ماهر حافظ و خالا عبدالدايم عبدالعال" الزال

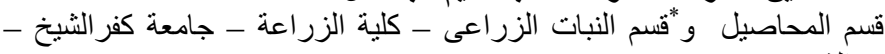

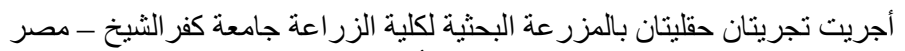

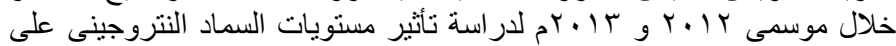

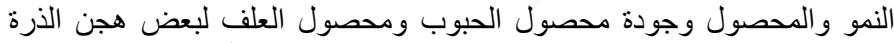

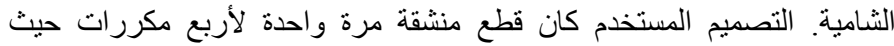

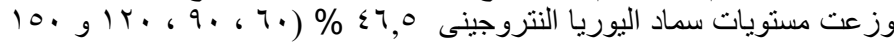

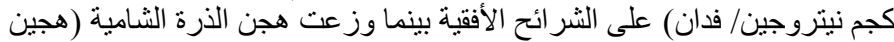

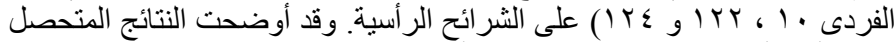

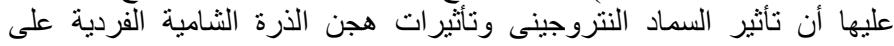

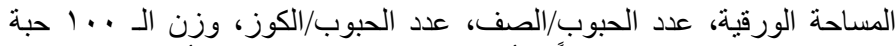

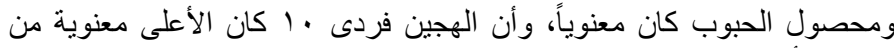

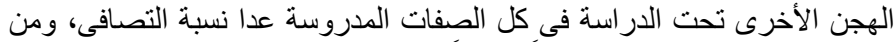

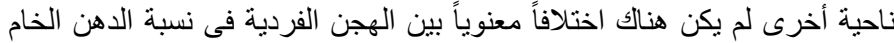

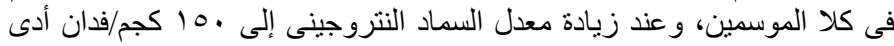

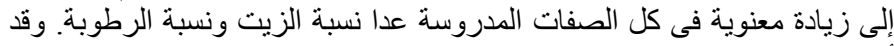

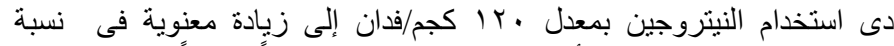

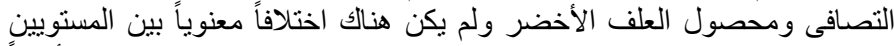

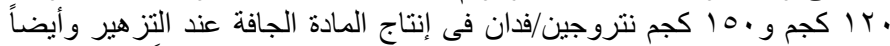

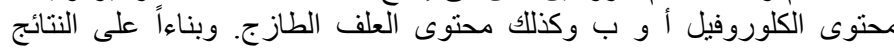

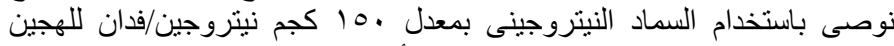

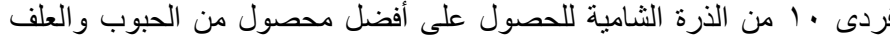
الطاز ج وكذلك أفضل جودة. 